\title{
BİLİMSEL HABERLER
}

1. Tezler;

1. Bio. Bottan Ş İM ŞEK

"Farelerde Akciğer Adenomu Oluşmasında C Vitaminin Önleyici Etkisi ve Akciğerde Prostoglandin Sentezi İle Olan İlişkisi" Doktora Tezi (1982).

2. Ecz. Şenay K ÜS MENO ĞLU

"Achillea VVilhelmsii C. Koch Bitkisi Üzerinde Farmakognozik Araştırmalar" Doktotora Tezi (1982).

3. Ecz. Mümtaz İŞCAN

"3-Metilkolantren, Fenobarbital ve Bazı Pestisitlerin Kobay Karaciğeri ve Akciğeri Karışık Fonksiyonlu Oksidazlar Enzim Sistemi Üzerine İn vivo Etkileri" Doktora Tezi (1982).

4. Ecz. Asuman KARAKAYA

"Türkiye'de Sık Olarak Zehirlenmelere Neden Olan İlaç ve Pestisitlerin XAD-2 ile İdrardan İzolasyon Koşullarının Araştırılması ve Bir Toksikolojik Analiz Tarama Yöntemimin Geliştirilmesi" Doktora Tezi (1982).

5. Dr. Pharm. Ali Esat KARAKAYA

"Di metil amino grubu İçeren Bazı Antibiyotiklerden, Mide koşullarında Nitrit Etkileşmesi ile Dimetilnitrozamin şekillenmesinin Araştırılması" Doçentlik Tezi (1982).

6. Ecz. Nurettin ABACIOĞLU

"Kandaki Anjiotensin II (A II) Konsantrasyonlarına İlaçların ve Elektroşokun Etkisi" Doktora Tezi (1982).

7. Ecz. Semra ŞARDAŞ

"Akdeniz Bölgesinde Yetişen Vicia faba L. (Bakla) Bitkisinin ve İzole Edilen Toksik Etkenlerinin Favizm Açısından Araştırılması" Doktora Tezi (1982).

8. Ecz. İlhan IŞIK

"Heterosiklik Halkalarla Sübstitüe Edilmiş Benzimidazol Türevlerinin Sentezi Yapı Aydınlatılması ve Yapı Etki İlişkileri Üzerinde Çalışmalar" Doktora Tezi (1982).

9. Ecz. Şahan SAYGI

"Organik Baz Yapısındaki Stimulan İlaçların (Doping Maddeleri) İdrardan İzolasyonları, Nitel ve Nicel Analizlerinin Kromatografik Yöntemlerle Araştırılması" Doktora Tezi, (1982). 
10. Ecz. Fatma ERG UN

"Cruciata taurica (Pallas ex Willd.) Ehrend. s. L. Üzerinde Farmakognozik Araştırmalar"' Doktora Tezi (1982).

11. Ecz. Neşe TUNÇEL

"In vivo ve In vitro Elektro Kimyasal Oksijen Tayini" Doktora Tezi (1982).

12. Ecz. Gülin G ÜVEN Dİ K

"Ankara'da Hava ve İnsanlarda Kan Kurşun Seviyesinin Araştırılması" Doktora Tezi (1982).

13. Ecz. Işsıl Ş İ M Ş E K

"Türkiye Piyasasında Satılan Meyva Suları ve Meyvalı Gazozların İçerdikleri C Vitamini Miktarları ve Taze Asılları ile Karşılaştırılması" Doktora Tezi (1982).

14. Ecz. Gülnur TOKER

"Türkiye'de Yetişen Tilia L. Türleri Üzerinde Farmakognozik Araştırmalar" Doktora Tezi (1982).

15. Ecz. Songül T ÜRKÖZ

"Cyclamen cilicium Boiss. et Heldr. var. intaminatum Miikle Bitkisi Üzerinde Farmakognozik Araştırmalar" Doktora Tezi (1982).

16. Ecz. Turan BAYKAL

"Pelargoinum endlicheriqnum Fenzl. Bitkisi Üzerinde Farmakognozik Araştırmalar" Doktora Tezi (1982).

17. Ecz. Seyhan ERSAN

"Antiviral Etkili Bazı 3 ve 5 Sübstitüe 1,2,4-Triazol Türevlerinin Sentezleri ve Bunların Biyolojik Etkileri Üzerinde Yapılan Çalışmalar" Doktora Tezi (1982).

18. Dr. Vet. Ahmet AKIN

"Ankara'da Çeşitli Kaynaklardan Soyutlanan Proteus'ların Biyoşimik Özellikleri, Proteosin'lerle Tiplendirimi ve Antibakteriyellere Dirençliliklerinin R-Plazmid'leri ile İlişkileri" Doçentlik Tezi (1982).

19. Ecz. Sevgi ŞAR

"İç Anadolu Bölgesi Halk İlaçlarının Eczacılık Tarihi ve Farmakognozi Açısından İncelenmesi" Doktora Tezi (1982).

20. Ecz. Fatma G Ü M Ü Ș

"2-(p-sübstitüefenil)-3H- İmidazo (4,5-c) piridin Türevlerinin Sentez, Yapı Aydınlatması ve Yapı-Etki İlişkileri Üzerinde Araştırmalar" Doktora Tezi (1982).

21. Ecz. Ali TOSUN

"Alfa-metilen benzo (d) Gama-Butirolakton (3-metilen-2, 3-dihidroben-zofuran2-On)'un Sentezi ve Yapı Aydınlatması" Doktora Tezi (1982).

22. Ecz. Cem AKINCIT ÜRK

"Deney Hayvanlarında Kolinesteraz İnhibitörleri ile Vitaminlerin Etkileşmeleri" Doktora Tezi (1982). 


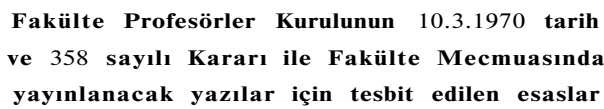

1) Dergide, başka bir mecmuada aynı isimle ve aynı tarzda neşredilmemiş orijinal çalışmalar yayınlanır.

2) Yazılar Komisyona verildiği tarih sırasıyla yayınlanır.

3) Metin 15 daktilo sayfasını geçmemek üzere Türkçe veya yabancı dilde yazılabilir. Metin başlığı ve özeti Türkçe ve yabancı dilde yazılacaktır.

Yabancı dilde yazılmış başlık, metin ve özetlerin dil kurallarına uygun olmasının temini, yazara aittir.

4) Yazılar, kâğıdın bir yüzüne, daktilo ile ve normal aralıkla yazılmalı, italik yazılacak kelimelerin altı çizilmeli, klişesi yapılacak grafik, şema, formül gibi şekiller, çini mürekkep ile, aydinger kâğıdına çizilmeli; fotoğraflar parlak kâğıda ve kontraslı olarak çekilmelidir. Şekillerin her biri ayrı kâğıtlarda olmalı ve kâğıdın üzerinde yazarın adı, kaçıncı şekil olduğu, resim altı yazılması istenen ibare kaydedilmelidir.

5) Yazı plânı aşağıdaki şekilde olmalıdır: Konunun takdimi, bulgular, denel kısım, münakaşa, Türkçe özet, yabancı dilde özet, literatür.

Konunun takdimi 2 daktilo sahifesini geçmemeli; materyal, metot ve yapılan ameliyeler "denel kısım" da yer almalı, "münakaşa" kısmı, gerekli ise konmalıdır.

Literatür, metinde parentez içindeki numaralarla belirtilmesi ve metin sonunda bu numaralara uygun olarak sıralanmalıdır. Sırasıyla yazarın soyadı, adının ilk harfi, mecmuanın milletlerarası kullanılan kısaltılmış ismi, cilt numarası (italik), sayfa ve içinde tarih yazılmalıdır.

6) Tashihler yazar tarafindan yapılacaktır.

7) Yazara 50 ayrı baskı verilir. 